\title{
Identifikasi Teknik Pengendalian Hama Penyakit Tanaman Cabai di Desa Kebonlegi Kecamatan Kaliangkrik Kabupaten Magelang
}

\author{
Catur Prihatiningrum ${ }^{1 *}$, Ahmad Fauzi Nafi'udin ${ }^{2)}$, Muhammad Habibullah ${ }^{3)}$ \\ $\left.\left.\left.{ }^{1}\right)^{*}, 2\right), 3\right)$ Universitas Tidar \\ email: caturprihatin111@gmail.com ${ }^{1)^{*}}$, fauzinafi45@gmail.com ${ }^{2)}$, \\ muhammadhabibullah@untidar.ac.id ${ }^{3)}$
}

\begin{abstract}
Abstrak
Tanaman cabai merupakan komoditas pertanian yang sering ditemui dalam kehidupan sehari-hari. Produktivitas tanaman cabai bergantung kepada iklim, lingkungan, serta hama dan penyakit. Hama penyakit yang sering menyerang tanaman cabai di Desa Kebonlegi Kaliangkrik adalah antraknosa, thrips, ulat grayak, busuk batang, dan bercak daun. Teknologi pengendalian hama penyakit yang digunakan petani di wilayah ini adalah pengendalian secara kimia dan pengendalian teknis yang tidak sempurna. Jenis bahan aktif yang digunakan dalam pengendalian hama penyakit adalah mankozeb 80\%, Azoksistrobin $200 \mathrm{~g} / \mathrm{l}$ dan difenokonazol, Asibensolar 1\%, abamektin, Spinetoram 60g/l dan methoxyfenozide $300 \mathrm{~g} / \mathrm{l}$, dan sipermetrin $50 \mathrm{~g} / \mathrm{l}$. Komponen pengendalian kultur teknis yang digunakan adalah sanitasi, rotasi tanaman, pemupukan, dan pengolahan tanah. Tidak diterapkannya pengendalian organik dikarenakan mayoritas petani mengendalikan hama penyakit tanaman menggunakan pestisida sehingga lingkungan tidak mendukung untuk diterapkannya teknik pengendalian organik. Selain itu, faktor kurangnya sosialisasi, pengetahuan, dan minimnya modal mengakibatkan pengendalian hayati tidak diterapkan.
\end{abstract}

Kata kunci: cabai, hama,kultur teknis, penyakit, pestisida

\section{Pendahuluan}

Tanaman cabai merupakan komoditas pertanian yang selalu dibutuhkan dalam kehidupan sehari-hari. Tidak adanya barang substitusi cabai sebagai produk hortikultura membuat nilai ekonomi produk hortikultura ini memiliki harga yang tinggi. Harga cabai yang fluktuatif sering kali menyebabkan inflasi dan mempengaruhi harga komoditas yang lain. Menurut data Kementerian Perdagangan harga cabai nasional pada bulan September 2020 Rp 30.000,-(Kemendag, 2020). Nilai tersebut akan berubah seiring terjadi perubahan iklim yang ada. Terjadinya perubahan iklim yang tidak mudah diduga akan mengakibatkan hasil produksi tidak stabil.

Produktivitas setiap tanaman harus tetap terjaga untuk menjaga ketersediaan produk. Perlunya teknik pengendalian yang tepat dilakukan untuk menghindari kerugian yang diakibatkan karena hama dan penyakit yang menyerang tanaman. Pengendalian hama tepadu (HPT) merupakan suatu teknik yang digunakan untuk mengendalikan terjadinya ledakan hama yang 
menyebabkan turunnya produktivitas hasil panen. Strategi pengendalian hama terpadu dapat dilakukan dengan (1) mengupayakan pertumbuhan tanaman yang sehat, (2) kegiatan pengendalian hayati, (3) menggunakan varietas tanaman yang tahan hama dan penyakit, (5) kegiatan pengendalian secara fisik, (6) kegiatan pengendalian menggunakan senyawa semiochemicals(Indiati \& Marwoto, 2017).

Upaya pengendalian hama dan penyakit tanaman yang umumnya dilakukan oleh petani tradisional adalah menggunakan pengendalian secara kimia yakni penggunaan pestisida dan secara kultur teknis. Bersadasrkan Peraturan Pemerintah No.7 Tahun 1973 dalam (Moekasan, et al., 2015), pestisida merupakan Semua zat kimia atau bahan renik dan virus yang digunakan untuk mengendalikan hama atau penyakit tanmaan yang merusak tanaman, bagian tanaman atau hasil-hasil pertanian serta semua hal yang dapat mengendalikan gulma, pertumbuhan yang tidak diinginkan, mengendalikan hama-hama air,dan atau hewan ternak. Kultur teknik merupakan salah satu prinsip penerapan pengendalian hama terpadu (PHT). Penerapan kultur teknis dalam konsep PHT yakni dengan melakukan pengelolaan lingkungan dengan memadukan teknik budidaya yang tepat untuk dapat meningkatkan pengendalian hama penyakit. Teknik manajemen lingkungan yang baik dapat mendukung pertumbuhan optimal bagi tanaman serta mengurangi populasi hama akibat lingkungan yang kurang sesuai serta memacu berfungsinya agensia hayati. Pengelolaan yang dilakukan diharapkan dapat meningkatkan kemampuan tanaman lebih tahan terhadap hama dan penyakit tanaman (Inayati \& Marwoto, 2015).
Hama dan penyakit yang menyerang tanaman cabai sangat sangat beragam. Namun, hama yang umumnya menyerang tanaman cabai adalah ulat grayak, kutu kebul, kutu putih, thrips dan aphid. Hama tersebut merupakan hama penting yang menyerang tanaman cabai. Sedangkan penyakit yang umumnya sering ditemukan di petani adalah antraknosa, virus kuning, busuk buah, busuk batang, dan bercak daun. Adanya hama penyakit tersebut dapat menurunkan nilai ekonomi produksi tanaman cabai karena hama dan penyakit tanaman dapat merusak hasil panen dan tanaman (Cahyono, et al., 2017).Penelitian ini dilakukan untuk mengetahui teknik pengendalian hama yang dilakukan oleh petani di Desa Kebonlegi, Kecamatan Kaliangkrik, Kabupaten Magelang.

\section{Metode Penelitian}

Penelitian ini dilaksanakan di Desa Kebonlegi Kecamatan Kaliangkrik Kabupaten Magelang pada 7 September 2020 hingga 10 Oktober 2020. Sasaran dari penelitian ini adalah petani cabai di Desa Kebonlegi yang bertujuan untuk mengidentifikasi teknik pengendalian hama dan penyakit yang digunakan. Identifikasi ini dilakukan untuk mengetahui tingkat pengetahuan petani tentang manajemen pengendalian dan penangan hama penyakit tanaman cabai. Penelitian ini menggunakan jenis penelitian survey dengan metode pengambilan data yang menggunakan kuisioner kepada petani sebagai responden. Data yang diperoleh dari petani digunakan sebagai data primer. Data primer yang diambil mencakup karakter petani dalam menangggulangi hama penyakit tanaman cabai. Analisis data penggunaan teknologi pengendalian hama penyakit menggunakan interval kelas. 
Menurut Amirullah dan Hadiyanti dalam Astuti dkk (2016) sebagai berikut :

$\mathrm{NR}=\mathrm{NST}$-NSR dan PI=NR:JIK

Keterangan:

NR : Nilai Range

NST : Nilai Skor Tertinggi

NSR : Nilai Skor Terendah

JIK : Jumlah Interval Kelas

PI : Panjang Interval Kelas

Panjang interval kelas adalah 0,75, maka nilai interval kelasnya adalah

\begin{tabular}{lll}
\hline No & Nilai Interval & Kesimpulan \\
\hline 1 & $1,00-1,75$ & Tidak baik \\
2 & $1,76-2,50$ & Kurang baik \\
3 & $2,51-3,25$ & Baik \\
4 & $3,26-4,00$ & Sangat baik \\
\hline
\end{tabular}

\section{Hasil dan Pembahasan Jenis Pengendalian}

Hasil dari penelitian ini terhadap teknologi pengendalian hama penyakit tanaman yang digunakan oleh petani petani cabai Desa Kebonlegi diperoleh hasil bahwa mayoritas petani menggunakan teknik pengendalian kimia dan teknis (lihat Gambar 1). Teknik pengendalian kimia merupakan teknik pengendalian organisme pengganggu tanaman berupa hama hama dan penyakit yang dikendalikan menggunakan bahan-bahan kimia berupa pestisida. Sedangkan pengendalian kurtus teknis merupakan pengendalian yang dilakukan secara preventif sebelum serangan hama terjadi dengan sasaran agar populasi tidak meningkat sampai melebihi ambang kendalinya (Inayati \& Marwoto, 2015). Hasil survey yang dilakukan didapatkan data teknik pengendalian secara hayati dan organic tidak dilakukan oleh petani cabai wilayah ini. Untuk lebih jelasnya dapat dilihat pada gambar berikut:

\section{Jenis pengendalian HPT}

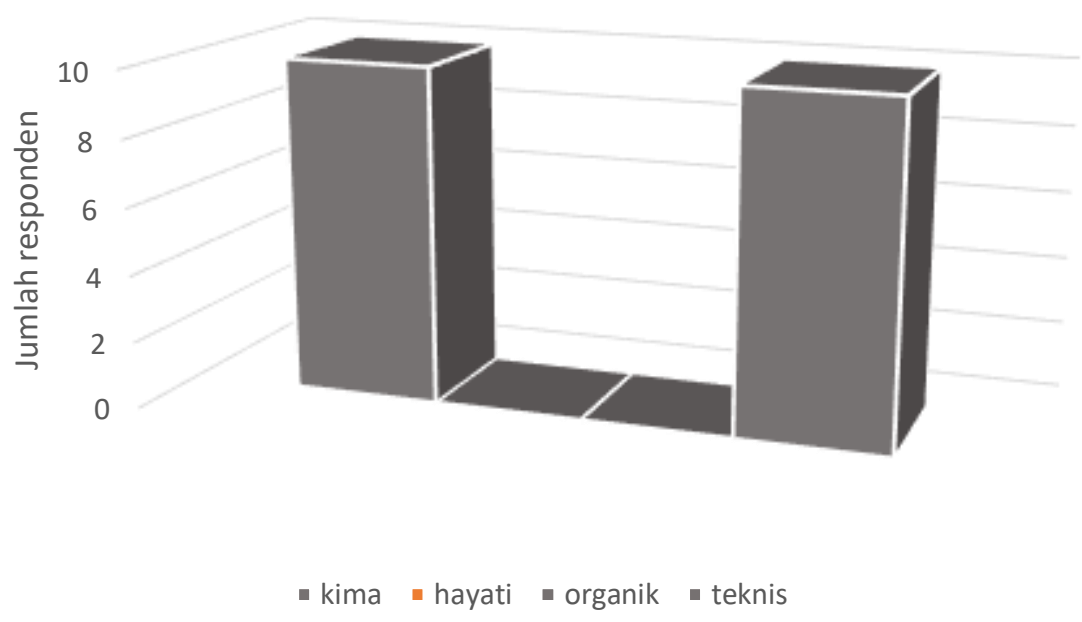

Gambar 1. Jenis Pengendalian Hama Penyakit Tanaman oleh Petani

Hasil yang diperoleh menunjukkan bahwa minat serta pengetahuan masyarakat terhadap pengendalian organik dan hayati kurang. Masyarakat berasumsi bahwa pengendalian hama penyakit tanaman adalah penyemprotan pestisida. Menurut Indiati dan Marwoto (2017) hal tersebut menunjukkan bahwa teknik PHT belum dikenal oleh petani. Hal ini dikarenakan petani masih bergantung pada penggunaan pestisida secara masif. Pemberantasan hama penyakit menggunakan pestisida yang berlebihan tidak efektif dan efisien dalam pengendalian hama yang akan 
berdampak bagi kesehatan dan lingkungan hidup.Pengendalian HPT secara organik tidak diterapkan karena lingkungan yang menggunakan pestisida sehingga pengendalian secara organik tidak akan efektif.

Teknologi pengendalian hayati di Desa Kebonlegi Kaliangkrik sangat rendah. Hal ini dikarenakan kurangnya sosialisasi terkait pengendalian hayati, kurangnya modal, serta kurangnya minat petani untuk beralih dari pestisida. Menurunnya musuh alami suatu hama diakibatkan karena berkurangnya hama sasaran. Berkurangnyahama sasaran ini karena penggunaan pestisida yang intensif (Subagyo dkk, 2017).

\begin{tabular}{|c|c|c|}
\hline Nama penyakit & $\begin{array}{l}\text { Jenis bahan aktif pestisida yang } \\
\text { digunakan }\end{array}$ & Prosentase \\
\hline \multirow{3}{*}{ Antraknosa } & -Mankozeb 80\% & $80 \%$ \\
\hline & $\begin{array}{cccc}\begin{array}{c}\text {-Azoksistrobin } \\
\text { difenokonazol }\end{array} & 200 & \mathrm{~g} / \mathrm{l} & \mathrm{dan} \\
& & \end{array}$ & $50 \%$ \\
\hline & - Asibensolar 1\% & $10 \%$ \\
\hline Thrips & Abamektin & $50 \%$ \\
\hline Busuk batang & Mankozeb $80 \%$ & $10 \%$ \\
\hline Ulat grayak & $\begin{array}{l}\text {-Spinetoram } 60 \mathrm{~g} / 1 \\
\text { methoxyfenozide } 300 \mathrm{~g} / \mathrm{l} \\
\text {-sipermetrin } 50 \mathrm{~g} / 1\end{array}$ & $\begin{array}{l}10 \% \\
10 \%\end{array}$ \\
\hline
\end{tabular}

Tabel 1. Penggunaan Jenis Bahan Aktif Pestisida

Bahan aktif pestisida yang digunakan mayoritas petani cabai di wilayah ini sama. Hal ini dikarenakan petani cenderung meniru saran dari petani lain karena keefektifan bahan aktif pestisida yang digunakan. Hal tersebut yang mengakibatkan petani tidak mau beralih menggunakan pestisida organic atau agen hayati untuk pengendalian penyakit karena tidak ada bukti nyata dengan hasil yang maksimal di wilayah tersebut.

Kegiatan pengaplikasian pestisida oleh petani umumnya dilakukan 5-7 hari sekali dalam seminggu. Pengendalian penyakit menggunakan pestisida dipilih karena hasilnya dapat dilihat dengan cepat dan praktis. Penggunaan pestisida secara tepat

\section{Bahan Aktif Pestisida}

Penyakit cabai yang umumnya ditemui oleh petani cabai di wilayah Desa Kebonlegi adalah penyakit antraknosa, thrips, busuk batang, ulat grayak, virus kuning, dan bercak daun. Jenis bahan aktif pestisida yang digunakan oleh petani di wilayah Desa Kebonlegi Kaliangkrik menggunakan pestisida dengan bahan aktif mankozeb $80 \%$ untuk pengendalian penyakit antraknosa. Sedangkan bahan aktif pestisida yang lain disajikan dalam Tabel 1. Penggunaan jenis bahan aktif pestisida adalah sebagai berikut: 
survey yang dilakukan adalah 1) sanitasi, 2) rotasi tanaman, 3) pemupukan, dan 4) pengolahan tanah.
Komponen tresebut disajikan sesuai dengan gambar 2. Komponen kultur teknis berikut:

\section{Komponen Kultur Teknis}

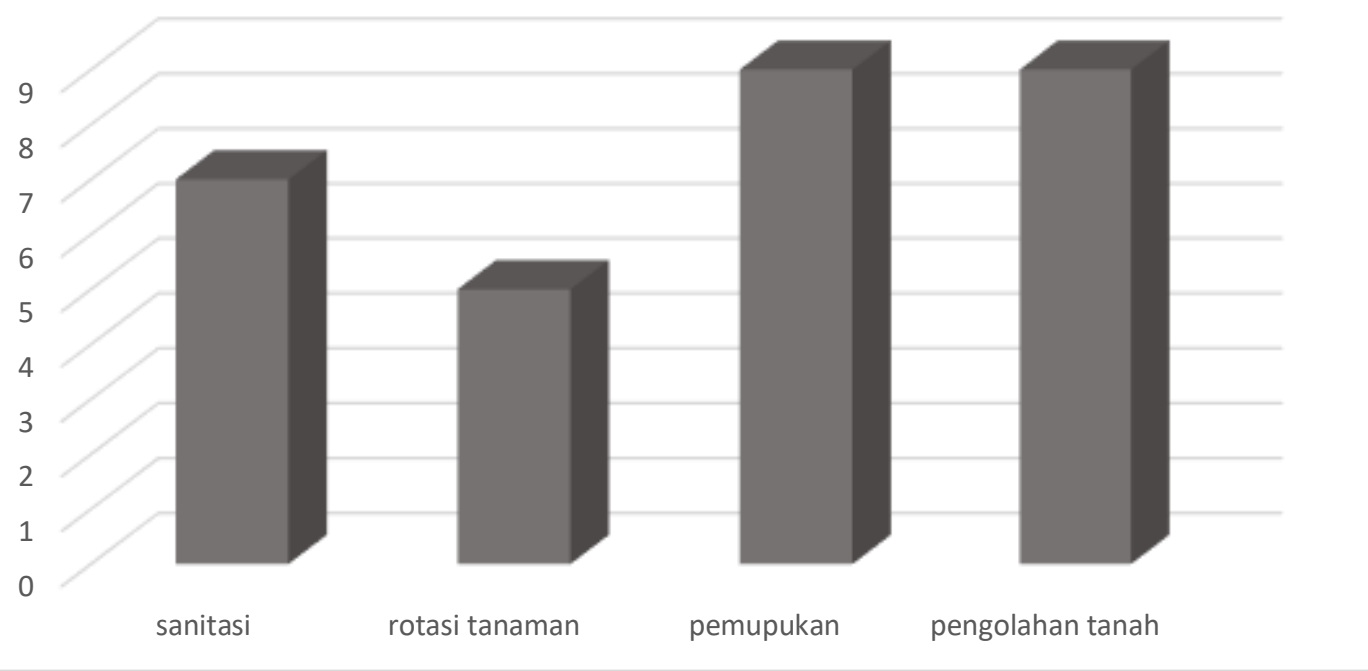

Gambar 2. Komponen Kultur Teknis

Berdasarkan grafik dan komponen tersebut masyarakat belum menerapkan teknik pengendalian ini dengan sempurna. Inayati dan Marwoto (2015) menyebutkan dalam penelitiannya bahwa komponen kultur teknis meliputi 1) pemilihan waktu tanam dan panen; 2) penggunaan varietas tahan penyakit; 3) penanaman tanaman penghalang; 4) system pengairan yang teratur; 5) pergiliran tanaman dan pola tanam; dan 6) sanitasi.

\section{Kesimpulan}

Teknologi pengendalian hama yang digunakan oleh mayoritas petani cabai Desa Kebonlegi Desa Kaliangkrik menggunakan pengendalian kimia. Kurangnya pengetahuan, sosialisasi, dan minimnya modal petani menyebabkan pengendalian hapa secara terpadu kurang banyak diterapkan, terlebuh tekbik pengendalian secara hayati. Frekuensi pengaplikasian pestisida yang terlalu sering akanmengakibatkan terjadinya resurgensi hama serta terjadinya kerusakan lingkungan.

\section{Daftar Pustaka}

Astuti, H. B., Fauzi, E., Yahumri \& H. R., 2016. Analisis Penerapan Teknologi Penanggulangan Hama Penyakit PAda Usahatani Cabai Merah Dataran Tinggi di Provinsi Bengkulu. AGRISEP, 15(2), pp. 127-134.

Cahyono, D. B., Ahmad , H. \& Tolangara, A., 2017. Hama pada Cabai Merah. Techno: Journal Penelitian, 06(02).

Inayati, A. \& Marwoto, 2015. Kultur Teknis Sebagai Pengendalian Hama Kutu Kebul Bemisia tabaci Genn. Pada Tanaman Kedelai. Buletin Palawija, 1(29), pp. 14-25.

Indiati, S. W. \& Marwoto, 2017. Penerapan Pengendalian Hama Terpadu (PHT) pada Tanaman Kedelai. Buletin Palawija, 15(2), pp. 87-100.

Kemendag, 2020. Sistem Pemantauan Pasar Kebutuhan Pokok $(S P 2 K P)$. [Online] 
Available

at:

https://ews.kemendag.go.id

Moekasan, T. K., Prabaningrum, L., Adiyoga, W. \& Putter, H. d., 2015. Modul Pelatihan Budidaya Cabai Merah, Tomat, dan Mentimun Berdasarkan Konsepsi Pengandalian Hama Terpadu. Wageningen UR, Netherland: vegIMPACT.

Oktavia, N. D., Moelyaningrum, A. D. \& Pujiati, R. S., 2015. Penggunaan Pestisida dan Kandungan Residu Pada Tanah dan Buah Semangka (Citrullus vulgaris, Schard) (Studi di Kelompok Tani Subur Jaya Desa Mojosari Kecamatan Puger Kabupaten Jember). Artikel Ilmiah Hasil Penelitian Mahasiswa.

Subagyo, V. N. O. et al., 2017. Pengendalian Hama Terpadu Pada Tanaman Cabai Di Kecamatan Cikajang Kabupaten Garut : Permasalahan Dan Profil Petani. Fauna, 16(2), pp. 26-34. 